International Journal of Engineering \& Technology, $7(2.12)(2018) 430-436$
International Journal of Engineering \& Technology
SPC
Website: www.sciencepubco.com/index.php/IJET
Research Paper

\title{
Augmentation of Mechanical Properties of Sisal Fiber Concrete
}

\author{
${ }^{1 *}$ M.Balasubramanian, ${ }^{2 *}$ Senthil Selvan.S, ${ }^{3 *}$ Vinod Panwar.D \\ ${ }^{1}$ Assistant professor, ${ }^{2}$ Professor, ${ }^{3} P . G$ Student \\ *Department of Civil Engineering, SRM Institute of Science and technology, Kattankulathur - 603203, Tamil Nadu, India \\ *Corresponding author E-mail: balasubramanian.m@ktr.srmuniv.ac.in
}

\begin{abstract}
The properties of sisal fiber concrete were examined in this investigation. To find out the mechanical properties such as compressive strength, flexural strength, tensile strength was carried out for the control concretes. The similar mix proportion which was utilized to cast control concrete was used to cast sisal fiber concrete were considered and evaluated with the theoretical values as recommended by IS 456 and BS 8110 standards. For comparison, both conventional and SF concrete have been considered to study. The mix design for M20, M30 and M40 grade of concrete was finished with four distinct proportions of control concrete in trail and error method as per IS10262 - 2009. Four distinctive aspect ratios, four distinctive dosages of fiber were added to the concrete mix to find out the optimum quantity of fiber and aspect ratio. Mix batches of concrete containing $0.5 \%, 1 \%, 1.5 \%, 2 \%$ dosage of fiber in the aspect ratio of 100, 200, 300 and 400 were cast. This study proves that the mechanical and bond properties of both SF concrete and conventional concrete as well.
\end{abstract}

Keywords: Sisal fiber concret; Mechanical properties of concrete; Compressive strength; Natural fibers

\section{Introduction}

Fiber reinforced concrete (FRC) is a concrete containing stringy material which constructs its assistant reliability to enhancing the properties of concrete. It contains small length discrete fibers that are reliably circled and randomly arranged. Fiber reinforced concrete might be characterized as a composite material made with cement, fine aggregate, coarse aggregate and discrete intermittent fibers. The part of randomly disperses intermittent fibers is to bridge across the cracks that develop provides some post cracking "ductility". The fibers have been utilized for mechanical considerable requirement of the concrete [1].

The fiber reinforced concrete has some important properties. such as durability, workability, compressive strength, tensile strength, modulus of elasticity, flexure, toughness, splitting tensile strength, fatigue strength, impact resistance [2] Fiber reinforced concrete is to improve blend union, enhancing pump capacity over long separations, improve solidify defrost resistance, improve imperviousness to hazardous sapling if there should be an occurrence of a serious fire, improve fire resistance, abrasion-resistance, increase imperviousness to plastic shrinkage at the time of curing, improve basic quality and improve ductility [3][4]

To study the replacement of conventional concrete with the sisal fiber concrete in the practical works. The sisal fiber concrete on aspect ratio of 100, 200, 300 and 400 respectively in which under eash aspect ratio the percentage of sisal fiber is about $0.5,0.1,1.5$ and 2.0. These concrete samples were subjected to compressive strength, tensile strength, flexural strength and bond properties of both SF concrete and conventional concrete were tested.

\subsection{Global production}

Global production of sisal fiber cultivated two hundred eighty-one thousand tons, of which Brazilthe top producing country made 150,600 tons. Tanzania cultivated on around thirty-seven thousand tons, Kenya made 27,600 tons, Venezuela 10,500 tons and 9,000 tons were cultivated in Madagascar. China contributed 40,000 tons with smaller amount beginning from Haiti, South Africa, Mozambique and Cuba. Sisal has sixth place among fiber plant, watching out for two percent of the world's course of action of plant fiber (plant fiber gives $65 \%$ of the world's fiber). As one of the world's important natural fiber, agave is secured by activities of the international year of natural fibers in 2009.

\subsection{Environmental impacts}

Sisal cultivating at first caused environmental degradation, since sisal plant replaced cultivation of native plants, yet it still viewed as less harming than other cultivation. No chemical fertilizers are used as a part of sisal cultivation, and despite the fact that herbicides are once in a while utilized; even this effect might be eliminated, since most weeding is finished by hand. The effluent from the decortication technique causes serious pollution when it is permitted to stream into conduits.[5]

\subsection{Effects of sisal fiber in concrete}

Fibers largely are used in concrete to conventional cracking by plastic shrinkage and drying shrinkage. They furthermore decrease 
the permeability of concrete and in this way, reduce bleeding of water. Sisal fiber concrete makes greater impact, abrasion, and shear resistance in bond. Sisal fiber concrete increases the flexural nature of the bond, and moment-resisting or essential steel reinforcement. Point of fact, that some fiber truly increases the durability of concrete.

\section{Materials Used}

As per Indian Standard IS 12269 (1987) Fifty-Three Grade ordinary Portland cement with specific gravity of 3.12 was used in this study for both SFC and conventional concrete for comparison[6]. Coarse aggregate of $20 \mathrm{~mm}$ and $12.5 \mathrm{~mm}$ maximum sizes were used for both SFC and CC, respectively. Fine aggregate used was River sand (from palar river bed) for the investigation conforming to grading zone III as per IS 383 (1970) for both SFC and CC as control concrete. Selection of fine and coarse aggregates was approached from IS: 383:1970for SFC and CC[3]. Water is an essential element of concrete as it helps the cement in chemical reaction. As per IS 456-2000 Clean convenient water was utilized. Aura mix 400 super plasticizer gives high workability to the concrete which helps in mixing and compacting of cement[7]. It enhances the nature of concrete by reducing its flaws of draining and segregation. Its workability increases due to its plasticizing properties, result in flowing concrete[8]. M20, M30 and M40 grade of concrete is chosen in view of the exposure of concrete conditions as per IS: 456:2000 principles[7].

Cactus comes under the member of the plant family Cactaceae. The cactus fiber classified into two types a) Agave b) Alovera. The agave classified into sisal or Agave sisalana. The idea of utilizing sisal fiber in cement was imagined. In light of the idea, different journals were alluded and thought regarding the characteristic fiber known as the sisal fiber being utilized as a part of cement was got [4]. Figure 1 show the structure of agave sisalana plant (sisal fiber)

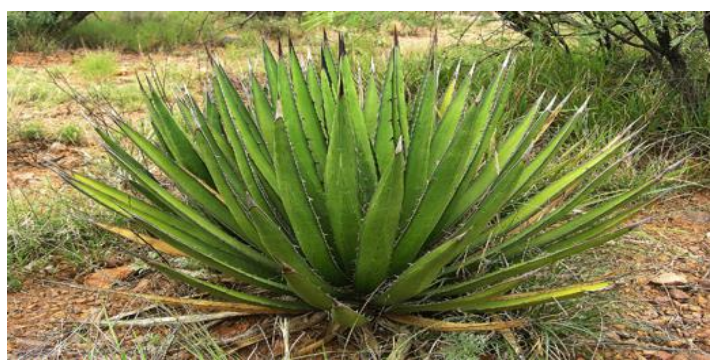

\subsection{Physical properties}

Fig-1 Agave sisalana

This fiber is yellow in shading and the physical properties are shown in table1. The physical appearance of sisal fiber is almost yellow in color, and it is a strong material which does not break easily under normal pressure [4]. The appearance of sisal fiber is shown in Figure-2.

Table-1Physical properties of Sisal Fiber

\begin{tabular}{lc}
\hline \multicolumn{1}{c}{ Physical Properties } & Result \\
\hline Thickness & $0.10 \mathrm{~mm}$ \\
Density & $0.02 \mathrm{~g} / \mathrm{cc}$ \\
Filler content & $2.13 \%$ \\
\hline
\end{tabular}
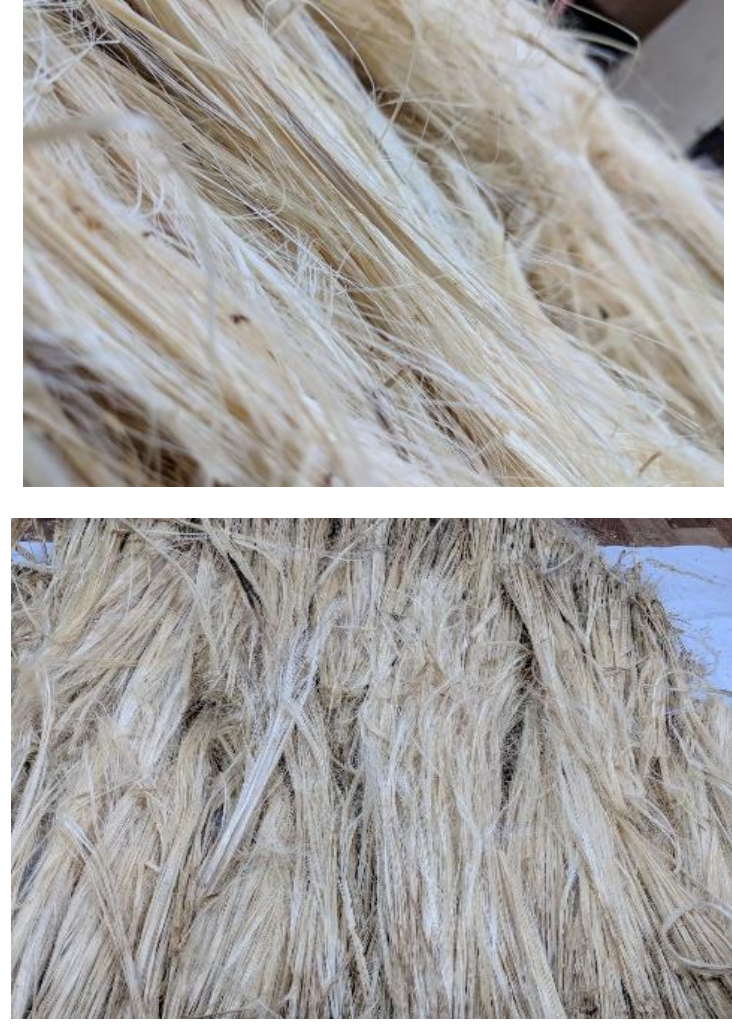

Fig- 2 Appearance of sisal fiber

\subsection{Chemical compositions}

The compound manifestations of sisal fibers have been represented by a several social occasions of researchers. The chemical composition of sisal fiber is shown in Table 2. Generally, the quality and strength of plant filaments depend on the cellulose present and the winding edges which the bundles of fibrils in the internal cell wall made with the fiber axis.

Table - 2 Chemical composition of sisal fiber.

\begin{tabular}{cc}
\hline Chemical composition & Percentage $(\%)$ \\
\hline Hemicelluloses & 18.1 \\
Cellulose & 71.5 \\
Pectin & 2.3 \\
Waxes & 0.5 \\
Lignin & 5.1 \\
Total & 100 \\
\hline
\end{tabular}

\subsection{Treatment of Sisal Fiber}

Thermal treated sisal fiber showed a significant improvement of mechanical properties due to the improved crystallinity of cellulose, which assures higher initial strength and maintains the reinforcing effect of sisal fiber in concrete for a long time. Sisal fibers were placed in a ventilated oven at $150{ }^{\circ} \mathrm{C}$ for 8 h. [9] The microstructure view of sisal fiber is shown in Figure-3. 

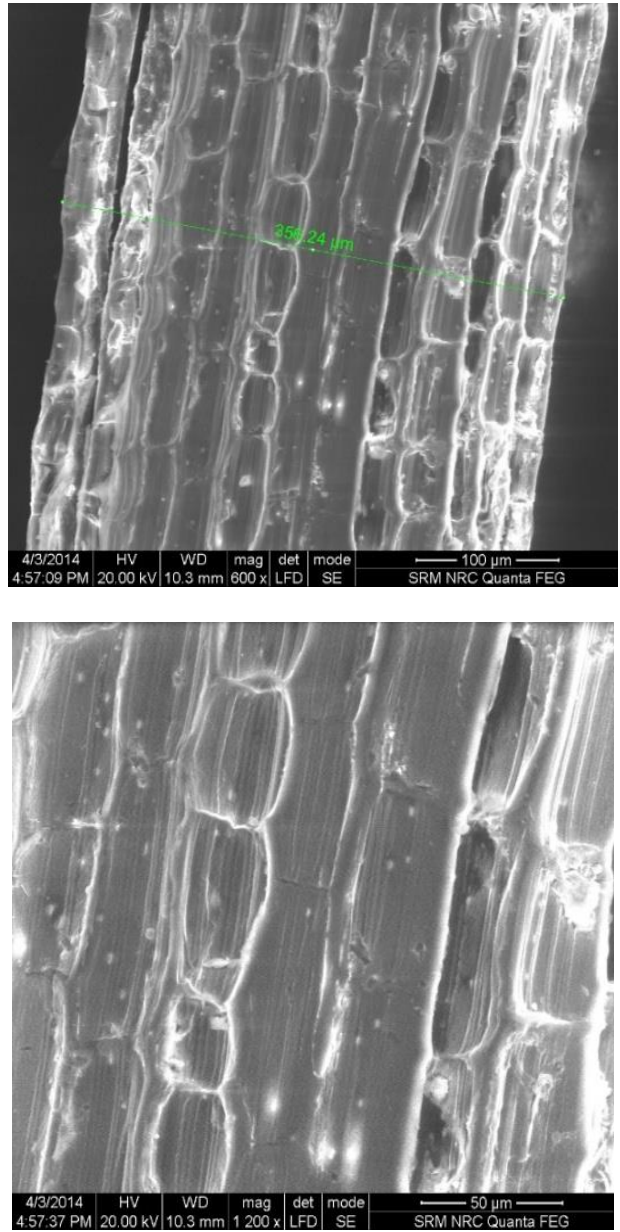

Fig-3 Microstructure view of sisal fiber

\section{Mix proportion}

Design of M20, M30 and M40 grade of concrete mix as per IS 10262-2009, Concrete mix proportioning-guidelines[10]. Numerous Mix proportions of concrete grades were carried out and conclude the mix ratio of various grade of concrete such as M20, M30, M40 was finalized the basic properties of compressive, split tensile and flexural strength of the concrete. The mix ratio of M20, M30 and M40 grade of concrete as shown in Table-3

Table 3 Mix proportions of concrete

\begin{tabular}{cccccc}
\hline $\begin{array}{c}\text { Grade of } \\
\text { Concrete }\end{array}$ & Cement & $\begin{array}{c}\text { Fine } \\
\text { Aggregate }\end{array}$ & $\begin{array}{c}\text { Coarse } \\
\text { Aggregate }\end{array}$ & W / C & $\begin{array}{c}\text { Super } \\
\text { Plasticizer } \\
\mathrm{Kg} / \mathrm{m}^{3}\end{array}$ \\
\hline M20 & 1 & 2.86 & 3.74 & 0.44 & 1.53 \\
M30 & 1 & 2.48 & 3.22 & 0.42 & 1.23 \\
M40 & 1 & 2.15 & 3.06 & 0.39 & 1.08 \\
\hline
\end{tabular}

\section{Specimen Casting and Testing}

The similar mix proportion which was utilized to cast conventional concrete was used to cast sisal fiber concrete. Four distinctive aspect ratios, four distinctive dosages of fiber were added to the concrete mix to find out the optimum quantity of fiber and aspect ratio. Mix batches of concrete containing $0.5 \%$, $1 \%, 1.5 \%, 2 \%$ dosage of fiber in the aspect ratio of $100,200,300$ and 400 were cast.The basic test on concrete such as flexural strength, compressive strength, tensile strength was carried out for the special concretes.[11]

\subsection{Compressive strength}

Compressive strength is the maximum compressive stress that, under a slowly connected load, a given concrete cube can sustain without cracks. Compressive strength is computed using the procedure as per IS516:1959 at the size of the cube is 100x100x100mm, in which nine concrete cubes were casted for each grade of M20, M30, M40 respectively for conventional concrete and sisal fiber concrete [12].



Fig-4a. Conventional Concrete before testing

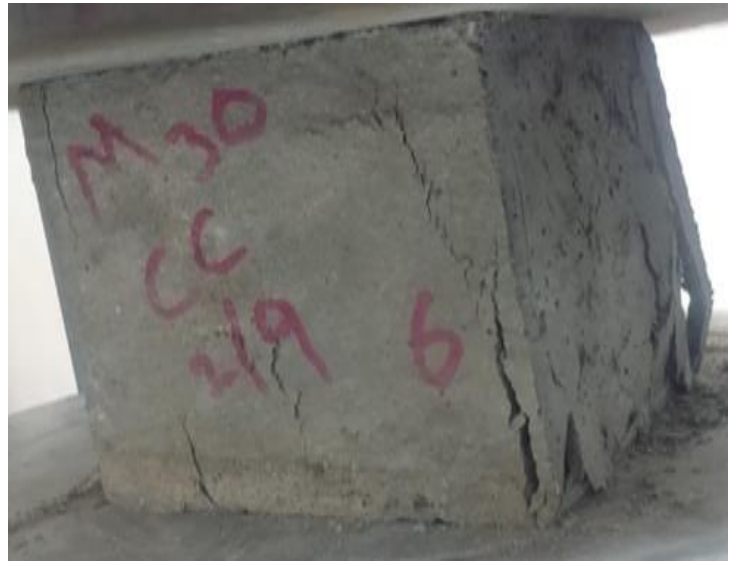

Fig- 4b. Conventional Concrete after testing

Figure 4(a) shows the conventional concrete cubes before subjecting to compressive loading whereas Figure 4(b) shows the conventional concrete cubes after compressive loading which implies the cracks on the cubes.

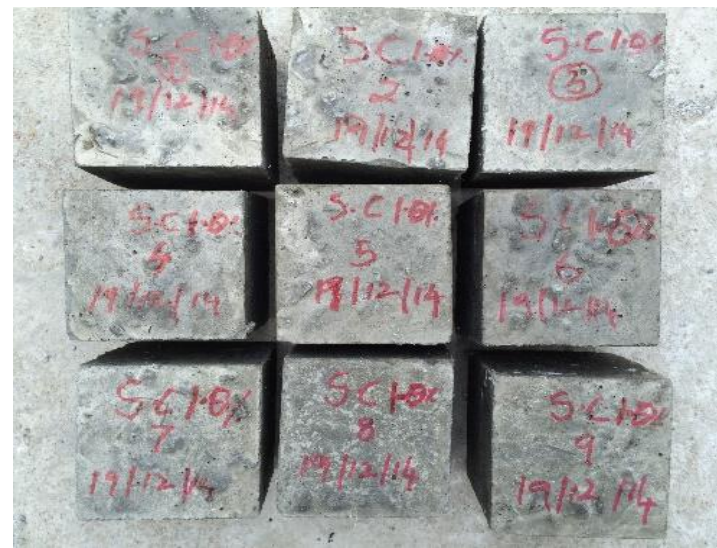

Fig-5a. Sisal fiber Concrete before testing 


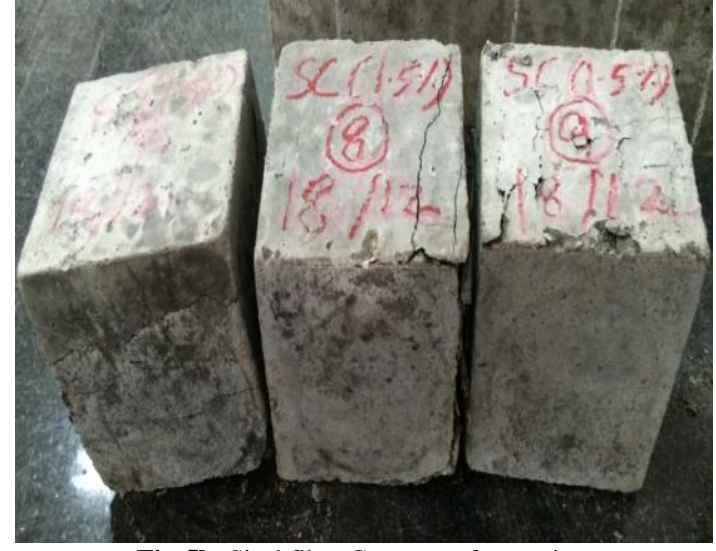

Fig-5b. Sisal fiber Concrete after testing

Figure 5 (a) shows the sisal fiber concrete cubes before sudjecting to compressive loading whereas figure 5 (b) shows the sisal fiber concrete cubes after compressive loading which implies the cracks on the cubes.

\subsection{Splite tensile strength}

Splite tensile strength is the fundamental and imperative properties of concrete.Split tensile strength is computed using the following formula as per IS516:1959 and the size of the cylinder is $100 \mathrm{~mm} \times 200 \mathrm{~mm}$, in which nine concrete cubes were casted for each grade of M20, M30, M40 respectively for conventional concrete and sisal fiber concrete.[12]

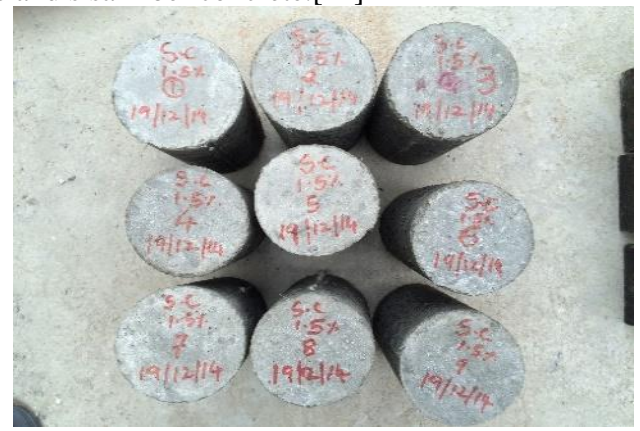

Fig-6a. Sisal fiber Concrete before testing

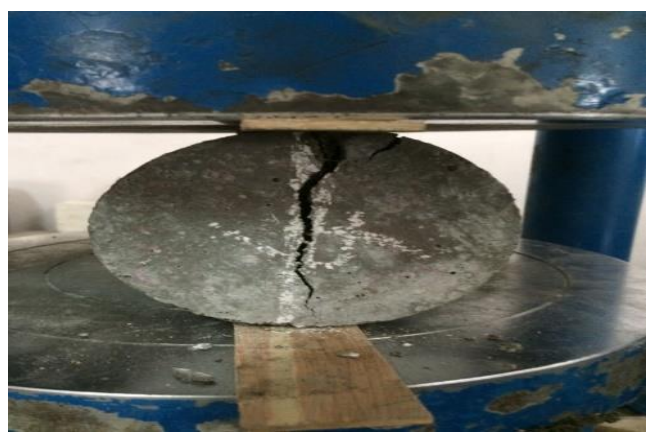

Fig-6b. Sisal fiber Concrete after testing

The above figure 6 (a), (b) shows the sisal fiber concrete cubes before subjecting to split tensile test wheras figure 6 (c) shows load acting on the sisal fiber concrete cylinder for split tensile strength testand figure 6 (d) shows the load acting on the conventional concrete after testing.

\subsection{Flexural strength}

Flexural strength is one measure of the elasticity of concrete. It is a measure of an unreinforced concrete beam or slab to oppose failure in bending. The flexural strength is also called as modulus of rupture. Flexural strength is calculated by using this formula as per guidelines of ASTM C 78-84 and the size of the beam is 500 mm length, $100 \mathrm{~mm}$ width and $100 \mathrm{~mm}$ depth.[13]

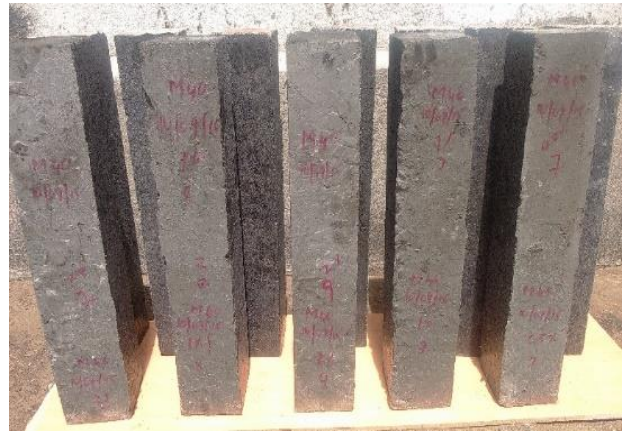

Fig-7a. Sisal fiber Concrete before testing

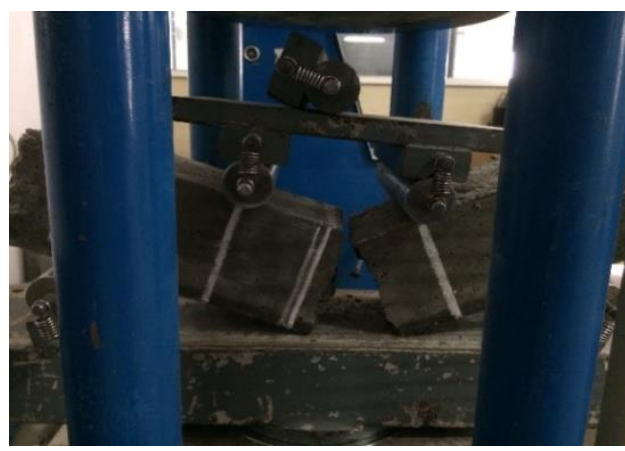

Fig-7b. Sisal fiber Concrete after testing

Figure-7 shows the concrete samples used for flexural testing. In which figure 7 (a) shows the sisal fiber concrete beams of grade M20, M30, M40 in which each grade contains nine beams before testing. Figure 7 (b) shows the sisal fiber concrete beams when subjected to the flexural loading leads to cracking

\section{Results and Discussions}

This result and discussion covers the comparison of compressive strength between theoretical and experimental values of the conventional concrete. The compressive strength of sisal fiber concrete which has the aspect ratio of $100,200,300,400$ which has the percentage of $0.5,1.0,1.5,2.0$ and there are nine cubes casted for each percentage of fiber aspect ratio and totally about 144 cubes were casted and subjected to the compression strength test. The comparison of vaues of the split tensile test and flexural loading of the concrete sample with the aspect ratio of 100, 200, 300,400 respectively as mentioned above.[14]

\subsection{Conventional concrete}

The comparison of compressive strength between the theoretical and experimental values are show in the below table 4 in which the average value between theoretical and experimental value of grade M20 is 4.51, for M30 is 3.52 and for M40 is 2.59 respectively[15].

Table-4 Comparison of Compressive Strength between Theoretical and Experimental

\begin{tabular}{|c|c|c|c|}
\hline \multirow[b]{2}{*}{$\begin{array}{l}\text { Grade of } \\
\text { Concrete }\end{array}$} & \multirow{2}{*}{$\begin{array}{l}\text { Theoretical Value of } \\
\text { Compressive } \\
\text { Strength of Concrete } \\
\left(\mathrm{N} / \mathrm{mm}^{2}\right)\end{array}$} & \multicolumn{2}{|c|}{ Experimental } \\
\hline & & Mix Ratio & $\begin{array}{l}\text { Compressive } \\
\text { Strength at } 28^{\text {th }} \\
\text { day }\left(\mathrm{N} / \mathrm{mm}^{2}\right)\end{array}$ \\
\hline M20 & 26.60 & $1: 2.86: 3.74$ & 27.80 \\
\hline M30 & 38.25 & $1: 2.48: 3.22$ & 39.60 \\
\hline M40 & 48.25 & $1: 2.15: 3.06$ & 49.50 \\
\hline
\end{tabular}




\subsection{Compressive strength of SFC}

The Compressive strength was carried out on M20, M30 and M40 grade of cubes with the aspect ratio of four various dosages of sisal fiber added to concrete mix 100, 200, 300 and 400. The test was carried out on three different stages 3rd day, 7th day, the 28th day of curing and the values where tabulated.[16]

The compressive strength of sisal fiber concrete on aspect ratio of $100,200,300$ and 400 respectively in which under eash aspect ratio the percentage of sisal fiber is about $0.5,0.1,1.5$ and 2.0 and nine samples were casted on each percentage of fiber based on curing such as 3 days, 7 days and 28 days resulting 144 cube samples were casted and the compressive load values are been showen in the graph bellow. [17]



Compressive Strength of aspect ratio 100

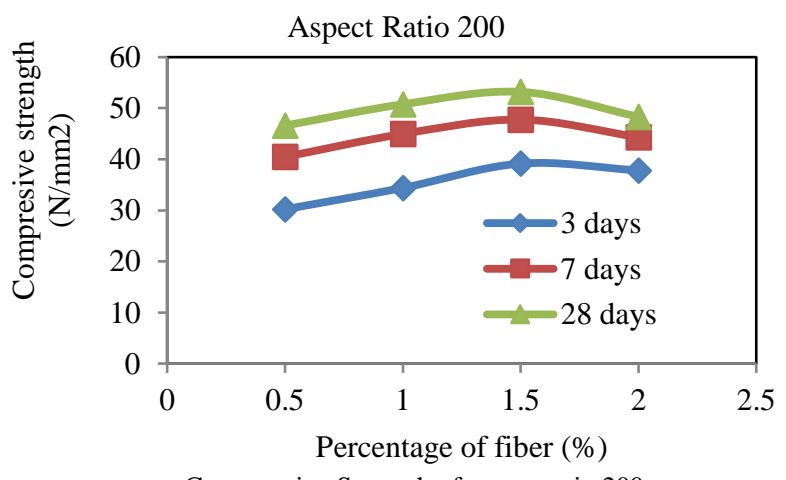

Compressive Strength of aspect ratio 200

Fig 8a Compressive Strength of concrete with aspect ratio of 100 and 200.

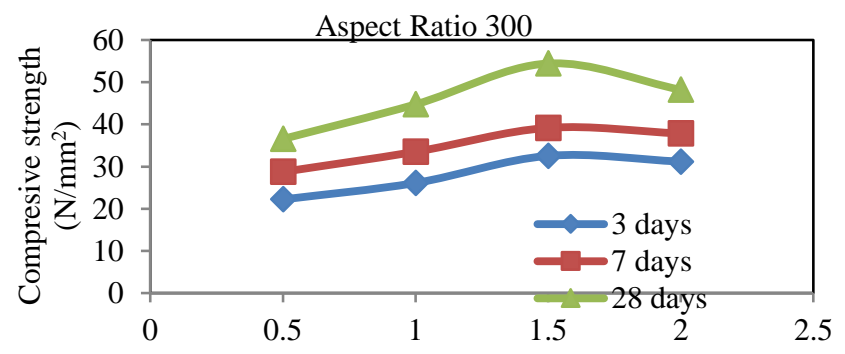

Percentage of fiber $(\%)$

Compressive Strength of aspect ratio 300.

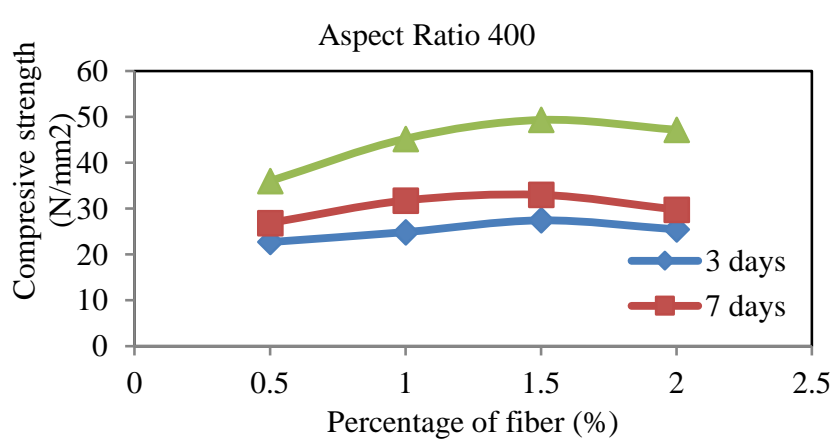

Compressive Strength of aspect ratio 400.
With the values a graph was plotted with compressive strength as the $\mathrm{y}$-axis and the percentage of fiber as an $\mathrm{x}$-axis, compressive strength results for 300 aspect ratio $1.5 \%$ fiber dosage is the optimum among all other dosage and aspect ratio of fiber shown in figure $8 \mathrm{a}$ and $8 \mathrm{~b}$.

\subsection{Split tensile strength on SFC}

The Split tensile strength was carried out on cubes with the aspect ratio of four various dosages of sisal fiber added to concrete mix $100,200,300$ and 400. The test was carried out on three different stages 3rd day, 7th day, 28th day of curing and the values where tabulated[18]

The split tensile strength of sisal fiber concrete on aspect ratio of $100,200,300$ and 400 respectively in which under eash aspect ratio the percentage of sisal fiber is about $0.5,0.1,1.5$ and 2.0 and nine samples were casted on each percentage of fiber based on curing such as 3 days, 7 days and 28 days resulting 144 cylinder samples were casted and the split tensile load values are shown in a graph bellow.[19].
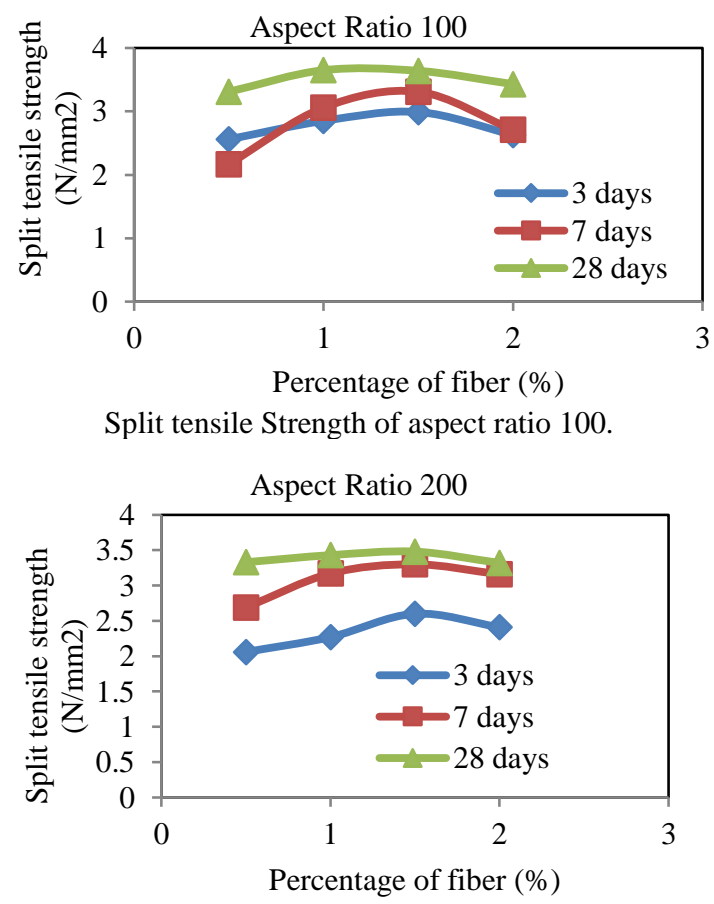

Split tensile Strength of aspect ratio 200.

Fig 9a Split tensile Strength of concrete with aspect ratio of 100 and 200.

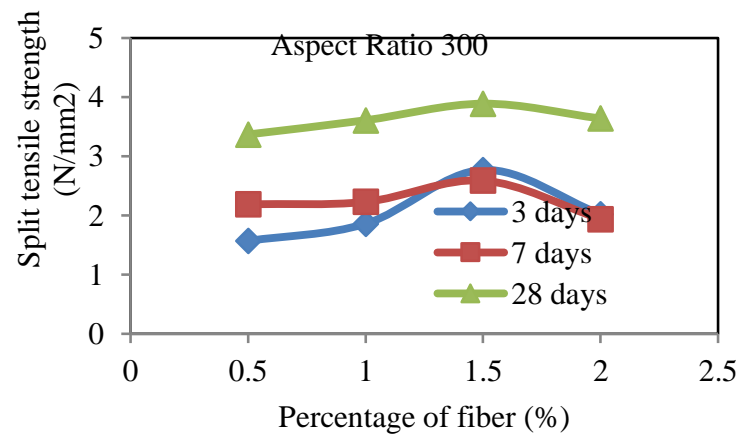

Split tensile Strength of aspect ratio 300 .

Fig 8b Compressive Strength of concrete with aspect ratio of 300 and 400. 


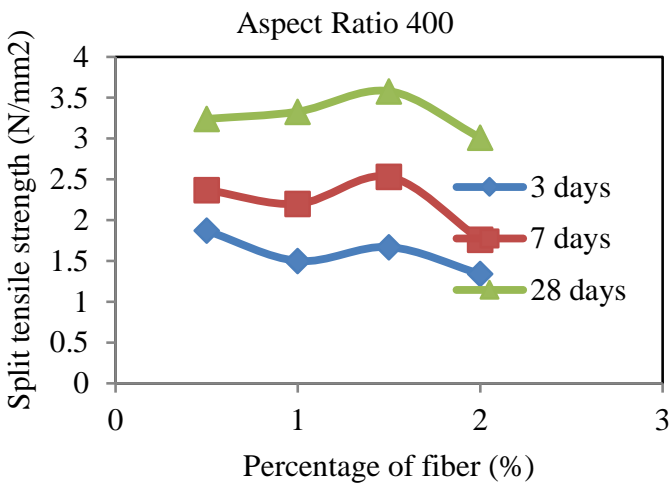

Split tensile Strength of aspect ratio 400.

Fig 9b Split tensile Strength of concrete with aspect ratio of 300 and 400 .

With above values, a graph was plotted with Split tensile strength as the $y$-axis and the percentage of fiber as an x-axis, Split tensile strength results for 300 aspect ratio $1.5 \%$ fiber dosage is the optimum among all other dosage and aspect ratio of fiber shown in figure $9 \mathrm{a}$ and $9 \mathrm{~b}$.

\subsection{Flexural strength of SFC}

The flexural strength was carried out on cubes with the aspect ratio of four various dosages of sisal fiber added to concrete mix 100, 200,300 and 400. The test was carried out on three different stages the 3rd day, 7th day, the 28th day of curing and the values where tabulated.[20][21]

The flexural strength of sisal fiber concrete on aspect ratio of 100,200, 300 and 400 respectively in which under eash aspect ratio the percentage of sisal fiber is about 0.5, 0.1, 1.5 and 2.0 and nine samples were casted on each percentage of fiber based on curing such as 3 days, 7 days and 28 days resulting 144 cube samples were casted and the flexural load values are shown in a graph bellow.

With above values a graph was plotted with flexural strength as the $y$-axis and the percentage of fiber as an $\mathrm{x}$-axis, flexural strength results for 300 aspect ratio $1.5 \%$ fiber dosage is the optimum among all other dosage and aspect ratio of fiber shown in figure $10 \mathrm{a}$ and $10 \mathrm{~b}$.



Flexural Strength of aspect ratio 100.

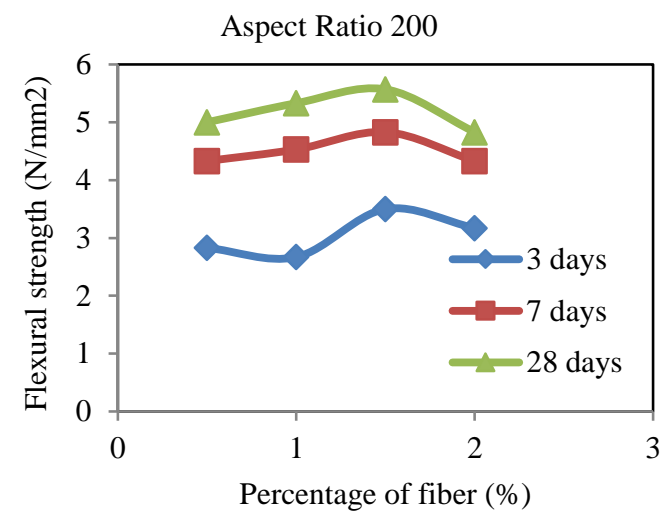

Flexural Strength of aspect ratio 200.

Fig 10a Flexural Strength of concrete with aspect ratio of 100 and 200.

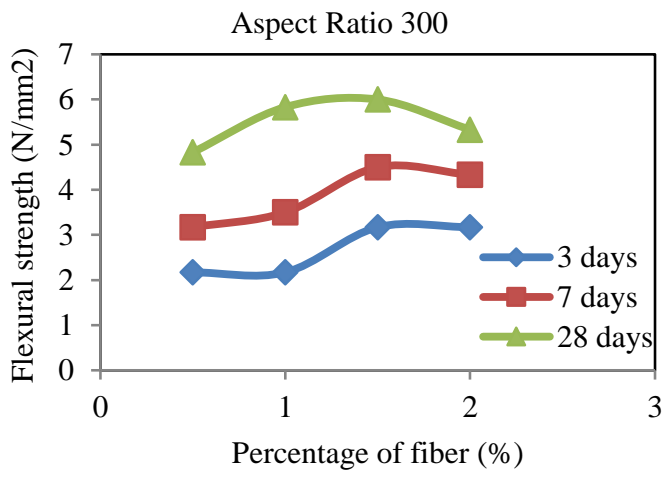

Flexural Strength of aspect ratio 300.

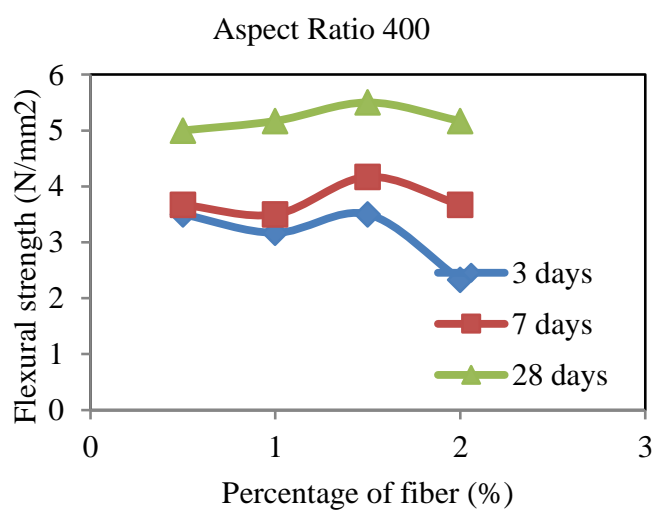

Flexural Strength of aspect ratio 400.

Fig 10b Flexural Strength of concrete with aspect ratio of 300and 400 .

\subsection{Comparative study}

Compressive strength ,Split Tensile strength, and Flexural strength result of 300 aspect ratio $1.5 \%$ fiber dosage is the optimum among all other dosage and aspect ratio of fiber.[14] The test results are given below in table 5 . 
Table 5 Average compressive, tensile and flexural strength.

\begin{tabular}{cccccc}
\hline \multicolumn{2}{c}{$\begin{array}{c}\text { Average } \\
\text { compressive } \\
\text { strength }\end{array}$} & $\begin{array}{c}\text { Average tensile } \\
\text { strength } \\
\left(\mathrm{N} / \mathrm{mm}^{2}\right)\end{array}$ & $\begin{array}{c}\text { Average flexural } \\
\text { strength } \\
\left(\mathrm{N} / \mathrm{mm}^{2}\right)\end{array}$ & \multicolumn{2}{c}{$\left.\mathrm{mm}^{2}\right)$} \\
\hline $\mathrm{CC}$ & SFC & $\mathrm{CC}$ & $\mathrm{SFC}$ & $\mathrm{CC}$ & $\mathrm{SFC}$ \\
49.5 & 54.30 & 3.1 & 3.87 & 3.8 & 5.83 \\
\hline
\end{tabular}

The determination of average Compressive strength, Split Tensile strength and Flexural strength results of $28^{\text {th }}$ day are shown in Table 5. and illustrated in the figure 11 .

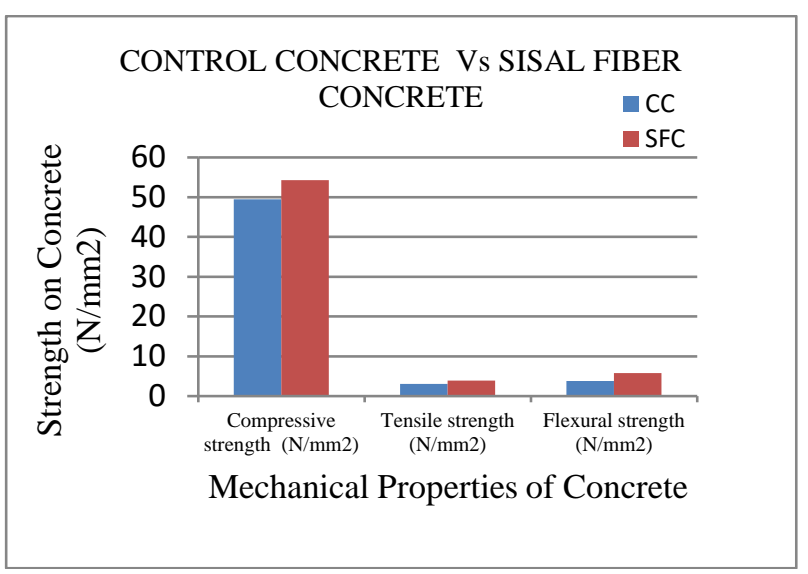

Fig 11 Mechanical properties of concrete

\section{Conclusion}

The Compressive strength, split tensile strength and flexural strength of sisal fiber concrete on aspect ratio of 100, 200, 300 and 400 respectively in which under eash aspect ratio the percentage of sisal fiber is about $0.5,0.1,1.5$ and 2.0. These concrete sample were subjected to compressive strength, tensile strength, flexural strength and the results are tabulated. Hence the Compressive strength results for 300 aspect ratio $1.5 \%$ fiber dosage is the optimum among all other dosage.

The tests were conducted and the resultant average compressive strength of CC was $49.5 \mathrm{~N} / \mathrm{mm}^{2}$ and SFC was $54.3 \mathrm{~N} / \mathrm{mm}^{2}$, and average tensile strength of CC was $3.1 \mathrm{~N} / \mathrm{mm}^{2}$ and SFC was 3.87 $\mathrm{N} / \mathrm{mm}^{2}$, and average flexural strength of $\mathrm{CC}$ was $3.8 \mathrm{~N} / \mathrm{mm}^{2}$ and SFC was $5.83 \mathrm{~N} / \mathrm{mm}^{2}$.

The impact resistance of SF concrete is high when compared with conventional concrete. The use of SF augments the impact resistance of concrete as well. The use of natural fiber enhances the concrete strength and is also environmental friendly.

The experimental bond strength of SF is much higher compared to the theoretical bond strength as recommended by IS 456:2000 and BS 8110 . Thus the use of SF enhances the mechanical properties of concrete in this experiment.

\section{References}

[1] S. P. Anandh K.S, Balasubramanian M, "An Experimental Study on Physical and Mechanical Properties of Agave Lechuguilla Fiber Used in the Concrete," vol. 10, no. 4, pp. 442-447, 2016.

[2] S. K. . Balasubramanian M, Senthilselvan S, "Experimental Studies of Sisal Fibre in Portland Cement Concrete Elements on Durability," vol. 10, no. 4, pp. 455-459, 2016.

[3] Bureau of Indian Standard(BIS), "Specification for Coarse and Fine Aggregate From Natural Sources for Concrete," IS 383(Second rev.), p. New Delhi,India, 1970.

[4] M. Balasubramanian, S. Senthilselvan, and K. V Sabarish, "Experimental Investigation on Strength and Durability Properties of Sisal Fiber Reinforced Concrete," vol. 14, pp. 241-246, 2016.

[5] K. Gunasekaran, S. Praksah Chandar, R. Annadurai, and K. S
Satyanarayanan, "Augmentation of mechanical and bond strength of coconut shell concrete using quarry dust," Eur. J. Environ. Civ. Eng., vol. 21, no. 5, pp. 629-640, 2017.

[6] IS: 12269-1987 (Reaffirmed 1999), "Specification for 53 Grade Ordinary Portland Cement," Indian Stand. Stand., vol. 1987, no. April 1988, 1999.

[7] ACI 440.2R-08, I. Standards, Bureau of Indian Standards, and BIS, "IS:1786-1985 Specification for High Strength Deformed Steel Bars and Wires for Concrete Reinforcement," ACI Comm. 440, p. 144, 2008.

[8] K. Gunasekaran, P. S. Kumar, and M. Lakshmipathy, "Mechanical and bond properties of coconut shell concrete," Constr. Build. Mater., vol. 25, no. 1, pp. 92-98, 2011.

[9] M. A. Adam, M. Said, A. A. Mahmoud, and A. S. Shanour, "Analytical and experimental flexural behavior of concrete beams reinforced with glass fiber reinforced polymers bars," Constr. Build. Mater., vol. 84, pp. 354-366, 2015.

[10] Bis:10262-2009, "Concrete mix proportioning- guidlines," Bureau of Indian Standards. .

[11]K. L. Pickering, M. G. A. Efendy, and T. M. Le, “A review of recent developments in natural fibre composites and their mechanical performance," Compos. Part A Appl. Sci. Manuf., vol. 83, pp. 98-112, 2016

[12] "IS-516-1959-Indian Standard methods of tests for strength of concrete. (Reaffirmed1999).".

[13]ASTM, "ASTM C78/C78M - 02 - Standard Test Method for Flexural Strength of Concrete (Using Simple Beam with ThirdPoint Loading)," ASTM Int., pp. 1-3, 2002.

[14]K. Gunasekaran, R. Annadurai, and P. S. Kumar, "A study on some durability properties of coconut shell aggregate concrete," Mater. Struct. Constr., vol. 48, no. 5, pp. 1253-1264, 2015.

[15]K. Gunasekaran, R. Ramasubramani, R. Annadurai, and S. Prakash Chandar, "Study on reinforced lightweight coconut shell concrete beam behavior under torsion," Mater. Des., vol. 57, pp. 374-382, 2014.

[16]R. 2004 BIS: 1199-1959, "Methods of sampling and analysis of concrete," Bur. Indian Stand. Dehli, 1959.

[17] V. C. Li, "A simplified micromechanical model of compressive strength of fiber-reinforced cementitious composites," Cem. Concr. Compos., vol. 14, no. 2, pp. 131-141, 1992.

[18]C. Girisha, S. Siddhartha, and G. Rangasrinivas, "Tensile Properties of Natureal Fiber-Reinforced Epoxy-Hybrid Composites," Int. J. Eng. Res., vol. 2, no. 2, pp. 471-474, 2012.

[19] J. P. Torres, L.-J. Vandi, M. Veidt, and M. T. Heiztmann, "Statistical data for the tensile properties of natural fibre composites," Data Br., vol. 12, pp. 222-226, 2017.

[20] T. Sen and H. N. J. Reddy, "Flexural strengthening of RC beams using natural sisal and artificial carbon and glass fabric reinforced composite system," Sustain. Cities Soc., vol. 10, pp. 195-206, 2014.

[21]M. Sood and G. Dwivedi, "Effect of fiber treatment on flexural properties of natural fiber reinforced composites: A review," Egypt. J. Pet., 2017. 